\title{
Fast inversion of rupture process of the 14 April 2010 Yushu, Qinghai, earthquake*
}

\author{
Yong Zhang $^{1} \quad$ Lisheng $\mathrm{Xu}^{1, *}$ Yun-tai Chen ${ }^{1,2}$ \\ ${ }^{1}$ Institute of Geophysics, China Earthquake Administration, Beijing 100081, China \\ ${ }^{2}$ School of Earth and Space Sciences, Peking University, Beijing 100871, China
}

\begin{abstract}
Four results of the rupture process of 14 April 2010 Yushu, Qinghai, earthquake, obtained by inverting the broadband seismic data of Global Seismographic Network (GSN) based on the inversion method of earthquake rupture process, were compared and discussed. It is found that the Yushu earthquake has several basic characteristics as follows: (1) There exist two principal sub-events which correspond to two slip-concentrated patches being located near the hypocenter and to the southeast of the epicenter. The rupture of the slip-concentrated patch to the southeast of the epicenter broke though the ground surface; (2) The peak slip and peak slip-rate are about $2.1 \mathrm{~m}$ and $1.1 \mathrm{~m} / \mathrm{s}$, respectively, indicating that the Yushu earthquake is an event with large slip-rate on the fault plane; (3) Overall the Yushu earthquake is a unilateral rupture event with the rupture mainly propagating southeastward. The strong focusing of the seismic energy in the southeast of the epicenter due to the "seismic Doppler effect" reasonably accounts for the tremendous damage in the Yushu city.
\end{abstract}

Key words: earthquake rupture process; fast inversion; 2010 Yushu, Qinghai, earthquake; earthquake emergency response

CLC number: $\mathrm{P} 315.3^{+} 2$

Document code: A

As reported by China Earthquake Network Center (CENC), an earthquake (epicentral location: $33.1^{\circ} \mathrm{N}$, $96.7^{\circ} \mathrm{E}$, focal depth $33 \mathrm{~km}$ fixed by location program) of $M_{\mathrm{S}} 7.1$ occurred in Yushu, Qinghai province, at 07:49 on 14 April 2010, Beijing Time (23:49, 13 April 2010 UTC). After occurrence of the earthquake, we made fast estimation for this earthquake by using the rupture process inversion method (Xu, 1995; Chen et al, 1996; $\mathrm{Xu}$ and Chen, 1996; Chen and $\mathrm{Xu}, 2000$; $\mathrm{Xu}$ et al, 2002; Zhang, 2008; Zhang et al, 2009) developed in the past two decades. For earthquake emergency, we have obtained and released the results of three versions within about two and half hours, five hours and two days after the earthquake occurrence, respectively. In this paper, we describe the results of four versions, with emphasis on the result of the latest version (the fourth version) of the Yushu earthquake rupture process, obtained on April 21 based on the relocated hypocentral location by CENC (epicentral location: $33.2^{\circ} \mathrm{N}, 96.6^{\circ} \mathrm{E}$, focal depth $14 \mathrm{~km}$ ).

\footnotetext{
* Received 5 May 2010; accepted in revised form 10 May 2010; published 10 June 2010.

+Corresponding author. e-mail: xuls@cea-igp.ac.cn

(c) The Seismological Society of China and Springer-Verlag Berlin Heidelberg 2010
}

The vertical components of broadband teleseismic P waves of Globe Seismic Network (GSN) were downloaded from the website of Incorporated Research Institute of Seismology (IRIS) for inversion. Green's function was calculated by reflectivity method (Kennett, 1983) based on the IASPEI91 globe standard velocity model (Kennett and Engdahl, 1991).

\section{Fault parameters}

In consideration of the fast moment tensor results (Nodal plane I: strike $119^{\circ}$ /dip $83^{\circ} /$ rake $-2^{\circ}$; Nodal plane II: strike $209^{\circ} /$ dip $88^{\circ} /$ rake $-173^{\circ}$ ) determined by Liu et al (2010), the nodal plane (strike $119^{\circ} /$ dip $83^{\circ}$ ) striking SE was chosen as the causative fault on the basis of the tectonic background of Yushu. We obtained the rupture process results by the linear inversion technique (Zhang et al, 2009) with rake variation.

\section{Fast inversion results of three ver- sions for earthquake emergency}

Figure 1 shows the seismic stations, source time function and static slip distribution on fault of the results 
of three versions obtained within two and half hours, five hours and two days after the Yushu earthquake occurrence. The number of seismic stations used for the three inversions are 13, 26 and 35, respectively. Although the number of the seismic stations used in these three inversions is different, the main features of the results are almost the same. They all indicate that the
Yushu earthquake consists of two sub-events which correspond to two slip-concentrated patches near the hypocenter and $10-40 \mathrm{~km}$ to the southeast of epicenter. They all also indicate that the Yushu earthquake is a unilaterally rupture event with the rupture mainly propagating southeastward.
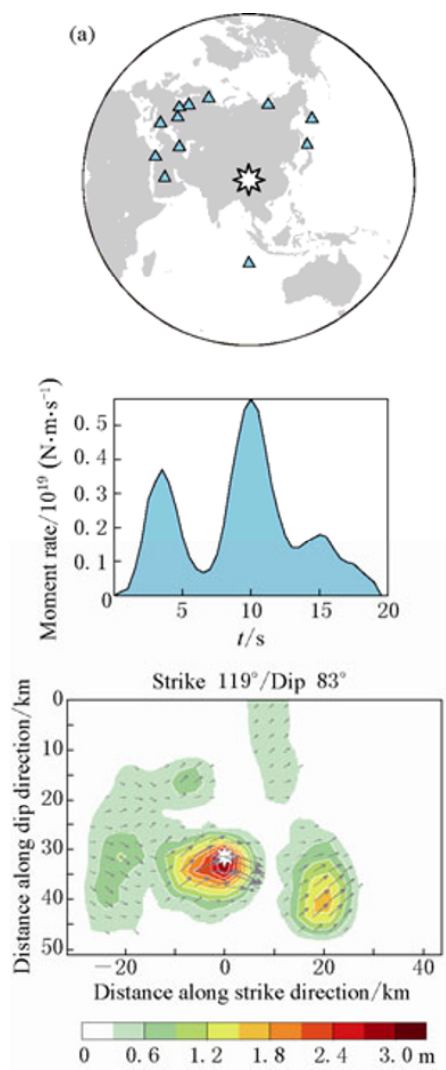
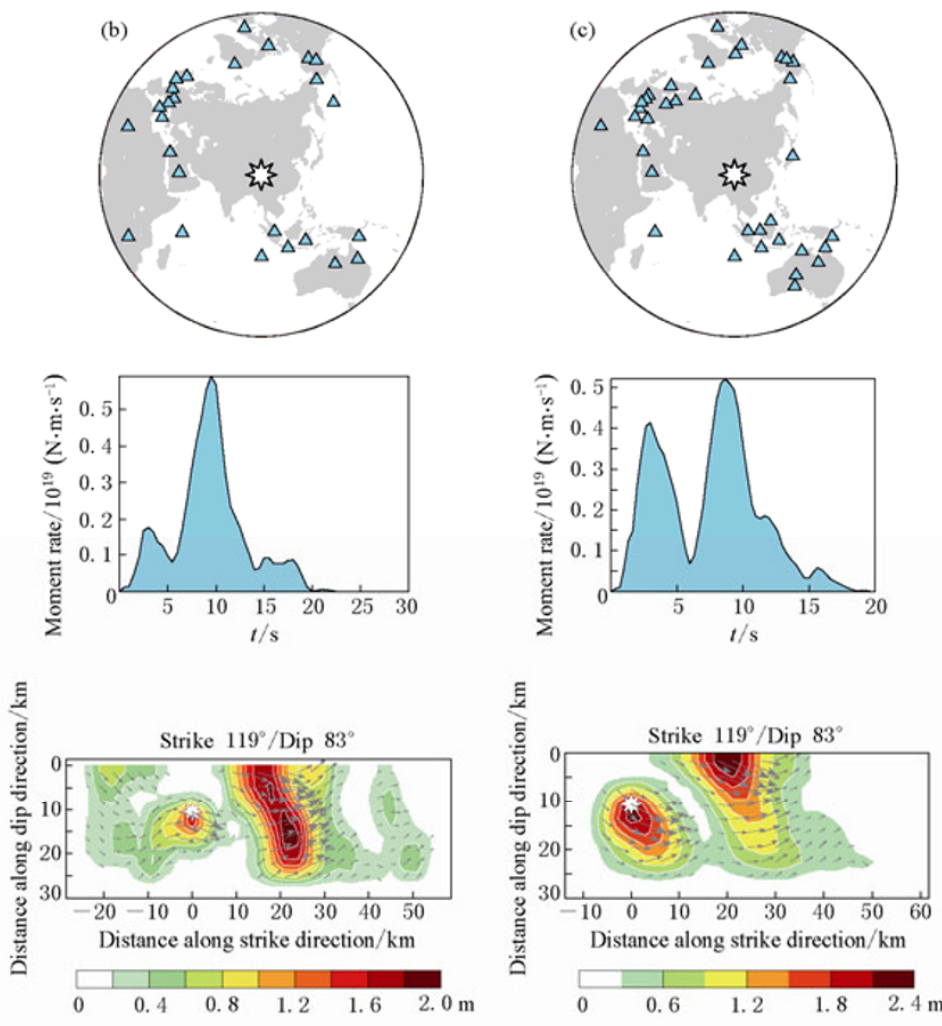

Figure 1 Fast inversion results obtained within two and half hours (a), five hours (b), and two days (c) after the occurrence of the Yushu earthquake. From top to bottom are the epicenter of Yushu earthquake (denoted by aniseed stars) and seismic stations (denoted by triangles), source time function and static slip distribution in (a), (b) and (c).

\section{The latest inversion result}

The latest inversion result is shown in Figure 2. Figure 2a shows the epicenter of Yushu earthquake and 35 seismic stations. By using a method with rake variation, the rupture process (Figure 2) of the Yushu earthquake was obtained. From slip distribution on the fault shown in Figure $2 b$, rupture mainly occurred on the fault plane (strike $119^{\circ} /$ dip $83^{\circ}$ ) with the length and width of about $50-70 \mathrm{~km}$ and $30 \mathrm{~km}$, respectively. The overall rake angle is about $-4^{\circ}$, indicating it is mainly a strikeslip event. There are two slip-concentrated patches (the deep red-red-yellow areas in Figure $2 b$ ) on the fault plane, the projections of which are located at the epicentral area, and an area $10-40 \mathrm{~km}$ away from the epicenter to southeast in the strike direction, respectively. The total ruptured area is about $1500 \mathrm{~km}^{2}$. The peak slip and peak slip-rate on the fault (deep red area in Figure $2 b$ and Figure 2d) are about $2.1 \mathrm{~m}$ and $1.1 \mathrm{~m} / \mathrm{s}$, respectively. Source time function shown in Figure 2c suggests that the Yushu earthquake consists of two sub-events whose maximum amplitude occurred at about $2.7 \mathrm{~s}$ and $7.7 \mathrm{~s}$ after the rupture initiation. The total scalar seismic moment $M_{0}$ is about $3.2 \times 10^{19} \mathrm{~N} \cdot \mathrm{m}$, which is equivalent to a moment magnitude $M_{\mathrm{W}} 6.9$. Projection of the slip distribution on ground surface (Figure 2d) shows that overall 


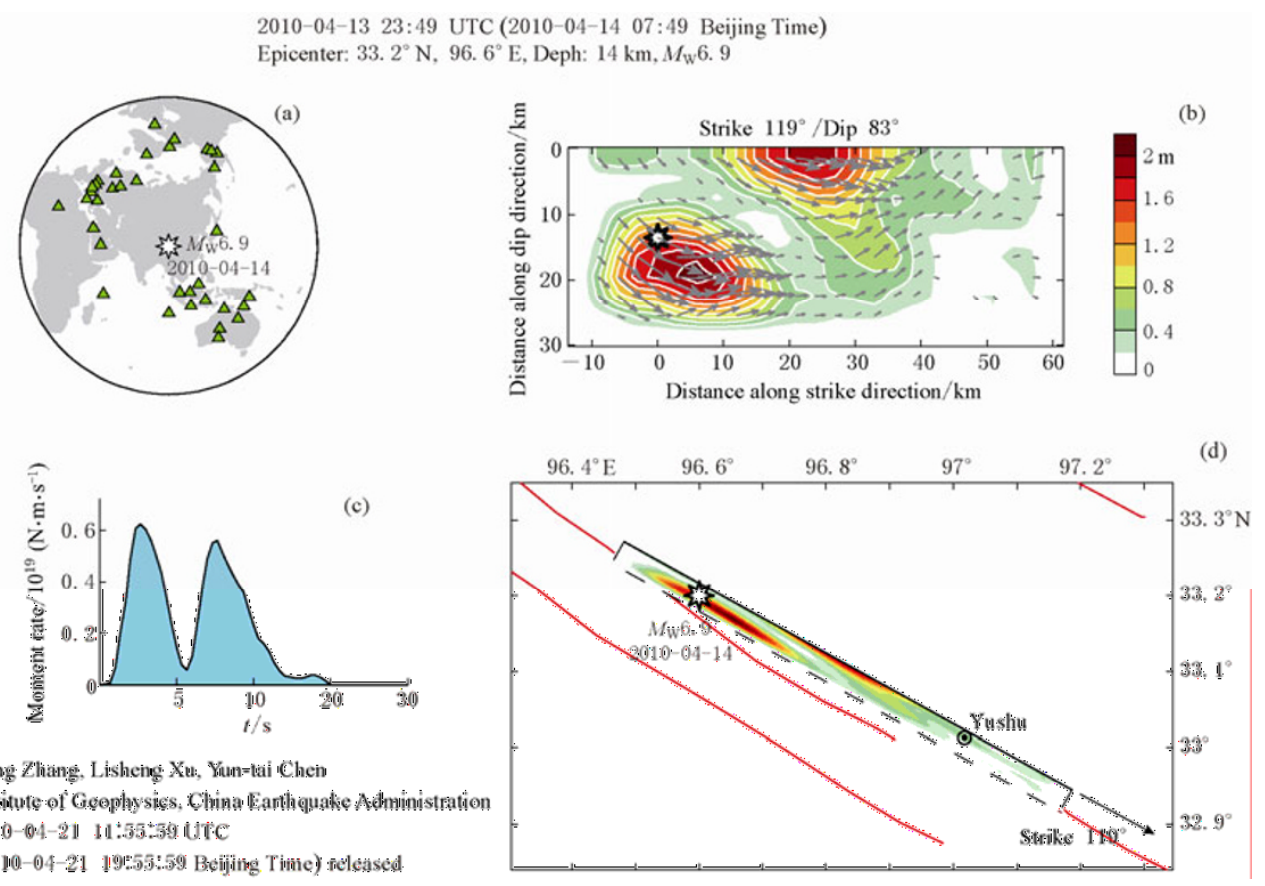

Figure 2 Rupture process results of 14 April 2010 Yushu earthquake. (a) Position of the epicenter of Yushu earthquake and seismic stations; (b) Static slip distribution; (c) Source time function; (d) Projection of rectangular fault plane and static slip distribution on the ground surface. Aniseed stars denote the epicenter location of Yushu earthquake in (a) and (d), and the hypocentral location on fault in (b). Full line in (d) represents the fault trace, i.e. the intersection of fault plane and ground surface. Dashed lines in (d) represent the projection of other three edges of the rectangular fault plane on the ground surface. Red lines in (d) represent active fault traces.

the Yushu earthquake is a unilateral rupture event propagating southeastward. It is concluded that the strong focusing of the seismic energy in the southeast of the epicenter due to the "seismic Doppler effect" reasonably accounts for the tremendous damage of Yushu city.

\section{Discussion}

The similarity of the four inversion results of the rupture process of the Yushu earthquake suggests that the main features of the rupture process of the Yushu earthquake can be retrieved even with a few stations data. Thus it confirms the necessity to carry out the fast inversion of the earthquake rupture process. The results obtained within a few hours after earthquake occurrence can offer valuable suggestions in earthquake relief and disaster mitigation.

Factors which may cause tremendous damage in the meizoseismal area include: (1) The first slip-concentrated patch located near the hypocenter but the second one located between the epicenter and Yushu city broke through the ground surface; (2) Although the peak slip is only $2.1 \mathrm{~m}$, the peak slip-rate is about $1.1 \mathrm{~m} / \mathrm{s}$. The peak slip-rate is comparable to the value of the 2008 Wenchuan earthquake $(1.2 \mathrm{~m} / \mathrm{s})$ (Zhang et al, 2009). It indicates that the Yushu earthquake is an event with high peak slip-rate; (3) The strong seismic Doppler effect caused by southeastward unilateral rupture propagation greatly increased the intensity in the area to the southeast of the epicenter and caused tremendous damage in the Yushu city (Figure 1d).

In consideration of the nearly pure strike-slip vertical fault, there may be a super-shear rupture during the rupture process of the Yushu earthquake (Zhang and Chen, 2006). In the inversions reported in this paper, we adopted a $6 \mathrm{~km} / \mathrm{s}$ threshold of the rupture velocity which is much larger than the shear wave velocity but no more than $\mathrm{P}$ wave velocity. However, this result is poorly constrained in $\mathrm{P}$ wave inversion in this study. Further work with other datasets such as surface wave inversion, or joint inversion of seismic data and geodetic data is needed.

Acknowledgments The authors thank the Incorporated Research Institutions for Seismology (IRIS) Data 
Center for providing high quality data. This work was supported by China Postdoctoral Science Foundation funded project (20080440435) and the project (DQJB09B06) from Institute of Geophysics (IGP), China Earthquake Administration (CEA). Contribution No. is 10FE3002, IGP-CEA.

\section{References}

Chen Y T and Xu L S (2000). A time-domain inversion technique for the tempo-spatial distribution of slip on a finite fault plane with applications to recent large earthquakes in the Tibetan Plateau. Geophys J Int 143 407-416.

Chen Y T, Xu L S, Li X and Zhao M (1996). Source process of the 1990 Gonghe, China, earthquake and tectonic stress field in the northeastern Qinghai-Xizang (Tibetan) plateau. Pure Appl Geophys 146(3/4): 697-715.

Kennett B L N (1983). Seismic Wave Propagation in Stratified Media. Cambridge University Press, Cambridge, 1-339.

Kennett B L N and Engdahl E R (1991). Travel times for global earthquake location and phase identification. Geophys J Int 105: 429-465.

Liu C, Xu L S and Chen Y T (2010). Fast solution of moment tensor of April 13, 2010 Yushu, Qinghai, earthquake. Acta Seismologica Sinica 32(3):
366-368 (in Chinese with English abstract).

Xu L S (1995). Study on the Tempo-spatial Rupture Process of Earthquakes. $\mathrm{PhD}$ Dissertation. Institute of Geophysics, China Earthquake Administration, Beijing, 1-102 (in Chinese).

Xu L S and Chen Y T (1996). Source time functions of the Gonghe, China earthquake retrieved from long-period digital waveform data using empirical Green's function technique. Acta Seismologica Sinica 9(2): 209-222.

Xu L S, Chen Y T, Teng T L and Patau G (2002). Temporal and spatial rupture process of the 1999 Chi-Chi earthquake from IRIS and GEOSCOPE long period waveform data using aftershocks as empirical Green's functions. Bull Seism Soc Amer 92: 3 210-3 228.

Zhang H M and Chen X F (2006). Dynamic rupture on a planar fault in three-dimensional half-space - II. Validations and numerical experiments. Geophys J Int 167: 917-932.

Zhang Y (2008). Study on the Inversion Methods of Source Rupture Process. $\mathrm{PhD}$ Dissertation. School of Earth and Space Science, Peking University, 1-158 (in Chinese with English abstract).

Zhang Y, Feng W P, Xu L S, Zhou C H and Chen Y T (2009). Spatio-temporal rupture process of the 2008 great Wenchuan earthquake. Science China (Series D) 52(2): 145-154. 